\title{
STRIKING INSIDE ANGOLA WITH 32 BATTALION
}

\section{Marius Scheepers}

\author{
Solihull: Helion \& Co Ltd \\ 2012, 184 pages \\ ISBN 978-1-920143-67-1
}

The Angolan Bush War or the South African Border War has become something of a forgotten war. In South Africa, the war was heard of, but the details were not known to the general public. For all practical purposes it was a 'secret war'. "Relatives and friends had no idea what their loved ones were going through while serving [on] the border" (p. 13). Today, many South Africans have a limited or distorted understanding of why there was a border war or, for that matter, few can explain why South Africa was entangled in a quagmire of that sort for years on end in Angola. The consistent stream of border war literature has tried to fill this void. The main contributors from South Africa were at first commanding officers (veteran colonels and retired generals) but thereafter numerous former conscripts. The declassification of information paved the way for aspiring researchers interested in uncovering this 'secret war'. More recently, the opposing sides have started to chronicle 'their side of the story' and record details of 'their' experiences. A recent contribution is that of Gennady Shubin and Andrei Tokarev. ${ }^{1}$

For many South Africans - both white and black - who sacrificed their lives in service of their country, the undertone of a 'forgotten war' is a bitter pill to swallow considering the sacrifices they were expected to make. For the duration of the war, life in South Africa continued almost unhindered (p. 13). It is for this reason, that Marius Scheepers - and many others before him - felt obliged to chronicle the untold stories and experiences of the Angolan Bush War. The first reality check for Scheepers came in about 1981 while he was still at school. On 12 August 1981, the pupils at Voortrekkerhoogte Secondary School learned overnight, the African National Congress (ANC) military wing Umkhonto we Sizwe (MK) launched stand-away attacks on the area, during which two rockets exploded near

Scientia Militaria, South African Journal of Military Studies, Vol 42, Nr 1, 2014, pp. 139-144. doi : $10.5787 / 42-1-1087$ the school. Scheepers frankly admits that the attack motivated him to contribute towards the prevention of future incidents of that kind ( $p$. 17). Moreover, accepting this challenge appeared to be less of a problem, as his father 
and two elder brothers were already commissioned officers in the South African Defence Force (SADF) (p. 17), which undoubtedly influenced his choices.

Marius Scheepers was born in Wesselsbron in the Free State province of South Africa. He completed his junior studies at Voortrekkerhoogte Secondary School, situated inside Thaba Tshwane military base, Pretoria. After matriculating, he served for two years in the military as part of the national service system (nasionale diensplig), a system of enforced conscription for all white able-bodied males. He began his training at the start of 1982 and, later that year, was deployed to operational base HQ at Ongiva Airport and the Tactical HQ at Londe as a signals officer to 32 Battalion, South Africa's most formidable fighting unit during the Angolan Bush War. After serving thirteen long months inside Angola, he returned home to start his tertiary education. By 1994, Scheepers had graduated twice with a BProc (Law), attained in 1989 at the University of the Free State, and an LLB (Law) in 1994 at the University of Pretoria. He is currently the director and owner of Marius Scheepers \& Company Labour Attorneys in Pretoria.

Striking inside Angola with 32 Battalion is Scheepers's first book. The title hints at what can be expected as, for the larger part of the war, 32 Battalion was the main fighting force that was used to strike inside Angola as part of the larger SADF's counter-insurgency (COIN) strategy against South West Africa People's Organization (SWAPO) and their perceived allies. The battalion was used effectively behind enemy lines and like the Reconnaissance Commandos ('Recces'), the unit deployed to areas which other units rarely saw. The battalion was used as a rapid force when contact was made either by the Recces, forces of the rebel movement, the National Union for the Total Independence of Angola (UNITA), or other regular SADF units. The book cover illustrates the conventional nature of the war and the technological level of the arms of the time. It depicts the smaller and lighter armed SADF Ratel 90mm capturing and destroying the superior Soviet T54/55 during Operation Askari inside Angola (1984). The pictures, although of relatively poor quality, are useful in helping the reader visualise the context. The work is also enriched by appendices containing incident reports, radio codes and pictures of weapons and equipment of belligerents, which cater for those who lack military knowledge. However, the table of contents and subtopics are less descriptive of the real content and could have been better.

Notwithstanding, the book provides an eye-witness account of a signals officer while on national service with the 'battle-respected' 32 Battalion during the Angolan Bush War. As a signals officer of the unit, Scheepers witnessed the tactical operations that were made inside Angola between December 1982 and 1983, and in all served for thirteen months with the unit (p. 16). The chronicle begins with 
Scheepers's training and departure to the operational base HQ at Ongiva in 1982 and concludes with addressing the war and its consequential impact on the society. Although the author briefly discusses the major operations, such as Askari and the battle of Cuito Cuanavale, the main emphasis is on events that took place between his arrival in December 1982 and his departure in January 1984. In writing this book, the author largely depended on his personal recollections, declassified documents and previous South African literature on the border war.

The significant feature of the book is the illustration of how the introduction of new and technologically advanced weaponry changed the tide of the war. For South Africa's part, modifications or rather Ratel variants, the Olifant tank, ZT3 anti-tank missiles, remotely piloted vehicles (RPV), G5 and G6 came in very handy during the war and made up for the inferior numbers compared to those of the opposing forces (p. 122-4). For the opposing forces, the introduction of SAM 7, 8 and 9 missiles, MIG 23, TMI-46 anti-tank mines and T-55 tanks were responsible for many SADF losses. In 1984, attempts were made to draw the war to a close. The Joint Military Monitoring Commission (JMMC) was established to keep the opposing forces apart and pave the way for negotiations (p. 80). On the one hand, South Africa maintained that any resolution to the war should be accompanied by the total withdrawal of Cuban forces. The Cuban/FAPLA forces on the other hand, wanted the withdrawal of South Africa from both Angola and South West Africa (SWA) (Namibia). Failing to reach an agreement, the JMMC collapsed and hostilities renewed. In the latter half of 1985 and again in 1986, FAPLA attempted to capture Mavinga and take Jamba, a UNITA stronghold to enable infiltration into SWA via the Caprivi Strip. The war erupted once more (p. 120).

After "shameful failures", according to the author (p. 120), the Cubans in particular were determined to redeem their military prowess and prestige. In 1987, now reinforced by the Cuban arsenal, FAPLA and its ally attempted to over-run Mavinga once more (p. 120-1). On this occasion, a series of battles ensued which culminated in the greatest battle of the war, namely that of Cuito Cuanavale. Aware of the grave conventional strikes on UNITA columns, South Africa launched Operation Modular to halt the advancing forces. After the objective had been achieved, hot pursuit of the enemy followed with Operation Packer. Although the battle was the largest in Southern Africa since World War II, the victor of Cuito Cuanavale is still debated by the opposing forces and their historians/war theorists. Scheepers, however, argues that the large conventional battles convinced the Cubanand Russian-backed FAPLA force that the SADF could not be defeated on the battlefield without a massive price to pay. The author ascribes much of the SADF success to a well-executed COIN strategy (p. 134-6). Scheepers notes that 
economically the war became a huge burden. In 1988, the war was costing the South African government R2 million a day. The prevailing economic sanctions at the time and the reduced number of economically active adults due to the enforced national service for white males further exacerbated the economic burden (p. 128). On the other hand, FAPLA military aid never seemed to dry up. However, the disintegration of the Soviet Union changed the political landscape and paved the way for the new international order. The perceived threat of the domino effect of communism on the continent was eliminated. However, economic consequences and expected casualties following any further conflict evidently became unbearable to all belligerents. The military stalemate demonstrated what was obvious from the beginning: the quagmire could only be settled through negotiations. The signing of the Geneva Protocol in 1988 and the long-awaited implementation of UN Resolution 435 marked the beginning of the end with the withdrawal of foreign forces from Angola.

In the epilogue, the author discusses the new emphasis of military history since the 1970s, namely war and society. This section reveals the effects of war on the general population and the battle-hardened soldiers after the war. "Many had resumed their civilian lives while suffering from post-traumatic stress" (p. 139). According to Scheepers, the SADF had neither the understanding that the veterans required counselling nor the capacity to provide such counselling. Similarly, South African society had too little knowledge about the war to understand the sufferings of the soldiers who had returned home. At the same time, senior officers struggled to come to terms with the lost autonomy they enjoyed during the war. Their sacrifices seemed to have evaporated with the war. As a consequence, many felt betrayed (p. 139).

Throughout the book, unnecessary grammar mistakes and technical errors are noticeable, which suggests that the book was not copy-edited, or if it was, the editing was not done properly. Repetition is also evident. Under the title "SWAPO forces", the author's impartiality is questionable or rather it seems that the author's had difficulty balancing the available evidence. The author focuses on SWAPO's modus operandi, its bases and those of the ANC. He then highlights the brutality that prevailed on the "other side", turning a blind eye to the brutality of South Africa's modus operandi in Angola and the still lasting social consequences (p. 36-42). These assertions are based mainly on one source. ${ }^{2}$ More and diversified sources would have added weight to the author's claims about brutality and a balance of atrocities caused by either side. ${ }^{3}$ In fact, the one-sided consultation of sources seems to be a problematic and persistent element in publications that appear inside South Africa on the Angolan Bush War. ${ }^{4}$ The primary sources used to recall the events of 
the war are recollections of South African officers and conscripts as well as top secrets documents of the operations. The sources of the opposing forces are hardly referred to which solidify the one-sidedness of the publications and how events actually unfolded. The author's claim of taking part in Operation Meebos is somewhat confusing as he asserted to have joined the battalion late December 1982, while Operation Meebos took place between July and August 1982 (p 17; 22). Such inaccurate articulation affects the credibility of the book. Given the limited declassified information, interviews with former compatriots would have added value to the research. The questions that arise from a layman's point of view on reading the title are: What precisely was the 32 Battalion? How did the battalion come about? And, why strike with it inside Angola? The author seems to have written the book assuming that his reader knows the background to the history of this fighting unit. Addressing these questions would have been informative, if not very useful, to readers since much of the history and the unit's activities were kept top secret and outside the public domain. The author did not do justice in painting a crisp and comprehensive picture of the more than notable contribution of 32 Battalion to South Africa's war effort.

The author's style of writing is reportorial rather than that of an interpretative historical account. Although Scheepers admits that the intention of the book was never aimed at giving comprehensive accounts of all 32 Battalion incursions during the period, many of the incursions are merely indicated by dates and not necessarily by setting the scene nor by providing informing context and actions. It would have been appropriate to take the reader on a historical journey through the atmosphere that alluded the period, as opposed to merely stating the incidences as the author had done in much of the book (p. 13). Complementing historical data and narrating the experiences of soldiers and commanders of the battalion would have provided both history and a real-life slice from the life of a unique unit. Military historians and experts on tactics might find the book less insightful. Historians may feel the work lacks the correct approach in writing history, especially in comparison with available literature such as Dr LJ Bothma's Buffalo Battalion: South Africa's 32 Battalion. A tale of sacrifice and Piet Nortjé's books on the 32 Battalion, the latest being The terrible ones: A complete history of 32 Battalion. For people who served during those times, Striking inside Angola with 32 Battalion will be a journey to relive the experiences, and the book will therefore act as reminder of the sacrifices they had made for their country. An avid reader of the Angola Bush War or contemporary South African history may find the book informative but not necessarily interesting due to the shortcomings pointed out. 
Thato Sebalane: Postgraduate student in Security and Africa Studies, Faculty of Military Science, (Military Academy), Stellenbosch University.

\section{Endnotes}

1 Shubin, G and Tokarev, A. Bush War: The road to Cuito Cuanavale. Soviets Soldiers' Accounts of the Angolan War. Auckland Park: Jacana Media, 2011.

${ }^{2}$ Groth, S. Namibia, The Wall of Silence: the Dark Days of the Liberation Struggle. Wuppertal: P.Hammer, 1995.

3 Trewhela, P. Inside Quatro: Uncovering the Exile History of the ANC and SWAPO. Auckland Park: Jacana Media, 2009 is the latest publication that substantially deal with atrocities committed by the ANC and SWAPO, while Shubin, G. The Oral History of Forgotten Wars: The Memoirs of Veterans of the War in Angola. Moscow: Memories Publishers, 2007 gives a relative balanced view of how the war became brutal in all facets.

${ }^{4}$ One example among many is the work by Malan, M. From Uniformed Technocrat to Securocrat. Pretoria: Protea Book House, 2006 which rarely makes use of the sources written on the war by other observers outside South Africa. Similarly, the 'opposing side' have begun chronicling the events from their perspective, such as the source I mentioned in the introduction of the review. 